\title{
Sediment Movements in Estuary of Siak River, Riau Basin, Indonesia
}

\author{
Mubarak and Ahmad Nurhuda \\ Department of Marine Science, Universitas Riau, Pekanbaru, Indonesia
}

Received: $2020-10-11$ Accepted: 2021-03-30

\author{
Keywords: \\ estuary; \\ hydrodynamics model; \\ total suspended solid; \\ sediment; \\ Siak River
}

Correspondent email:

dr.mubarak1269@gmail.com

\begin{abstract}
Siak river has a long history as a transportation lane in the east of Sumatera. From traditional to timber transportations are dependent on this river. Now the river is a severe suffering pollutant spill from many sources. Anthropological activities were higher contributions in the degradation of river environments. Many works were reported about pollution in Siak river. But how the distribution of model sediment transport in the mouth of the river is less to be explained. We consider hydrodynamics model of the mouth of Siak river for modeling the sediment distribution. This simulation gives a fundamental and clear understanding of how total solid sediment (TSS) distribution when flood and ebb tide happens. At ebb tide, TSS dispersion is higher than at flood tide. There is found that the sediment is concentrated in the plume of Siak river in Bengkalis strait. The composition of the sediment is dominated by organic matters.
\end{abstract}

๑2021 by the authors. Licensee Indonesian Journal of Geography, Indonesia.

litions of the Creative Common

Attribution(CC BY NC) licensehttps://creativecommons.org/licenses/by-nc/4.0/.

\section{Introduction}

Situated in a region of lowland rain- and mangrove forest in eastern Sumatra, the Siak river is the deepest in Riau province and an important conduit for trade in the region (Barnard, 1998). The Siak River has a length of more than 200 $\mathrm{km}$ and a catchment area of $11.500 \mathrm{~km}^{2}$ (Baum et al. 2007). The river crosses five municipal cities in Riau Province, namely (from upstream to downstream) Rokan Hulu, Kampar, Pekanbaru, Siak and Bengkalis. The existence of this river supports the economic path of the areas crossed by the Siak river which can accommodate ocean-going vessels (Cecil et al. 1993).

High input sediment in Siak river has declined the depth of River time by time. As one of tropical blackwater rivers in Sumatra Island, Siak river resettles much organic material from peatland (Baum et al. 2007; Liebezeit et al. 2014). Moreover, domestic and industrial waste also gathered in this river. All these sediments are carried in the estuary and form sedimentation. The sedimentation process is related to its relationship with accumulated sediments, suspended sediments and sediment fraction characteristics. Classification in sediment statistical parameters and sediment distribution can describe the condition of the aquatic environment of several oceanographic factors that influence the surrounding sedimentation process (Fan et al. 2012). The sedimentation process can be easily described with hydrodynamic studies.

In this paper, we investigate the contribution of tide activities on TSS dispersion in estuary Siak river to Bengkalis Strait. To study TSS distribution in Siak estuary and Bengkalis straits, we develop simulation of hydrodynamics model of the area generated by package software MIKE 21. This software is popular for many hydrologists and marine scientists because of its versatility for coastal modeling (Davies et al. 2009; DHI 2011; Menendez et al. 2013). The hydrodynamic module in MIKE 21 is a general numerical modeling system for the simulation of water levels and flows in estuaries, bays and coastal areas; it simulates unsteady twodimensional flows in one layer. In our case, we model the transportation of TSS and its distribution around Siak estuary and Bengkalis strait. The objective of this simulation was to determine the contribution of the Siak River to the condition of the water in the Bengkalis Strait.

\section{Method \\ Study location}

This study was carried out in estuaries of the Siak river estuary and Bengkalis straits, Riau Province Indonesia as depicted in Figure 1. Mean annual rainfall in the location is 3,300 mm with a brief dry season in February and a rainfall season in June-August, with mean daily temperature $27.2{ }^{\circ} \mathrm{C}$ and daily evapotranspiration $3.9 \mathrm{~mm}$ (Yupi et al. 2016). Siak river is a relatively quiet and safe water zone which preferred for many boats and ship lanes. The location is the main water lane for society from several coastal cities, such as Bengkalis, Dumai, and Selatpanjang, to trip Pekanbaru city, the capital city of Riau province. There are many industries depend on the River such as sailing, timber and coals transport. In the land area downstream of the Siak River there are several industries.

Physically the Siak River has the following characteristics: a length of approximately $300 \mathrm{~km}$, a depth between 7-14 m and a discharge ranging from $110-423 \mathrm{~m}^{3} / \mathrm{s}$, has a crossshaped shape with steep cliffs and has a width reaching 100150 meters, see Figure 2. Because the Siak river empties into the waters of the Bengkalis Strait, so it is included in the system of the Malacca Strait. The tidal pattern is a dual daily tide or semidiurnal.

The depth of the Bengkalis Strait is shallower than $30 \mathrm{~m}$ as depicted in Figure 2. The bathymetric was provided by MIKE 21 with some adjustments for correction. The water 


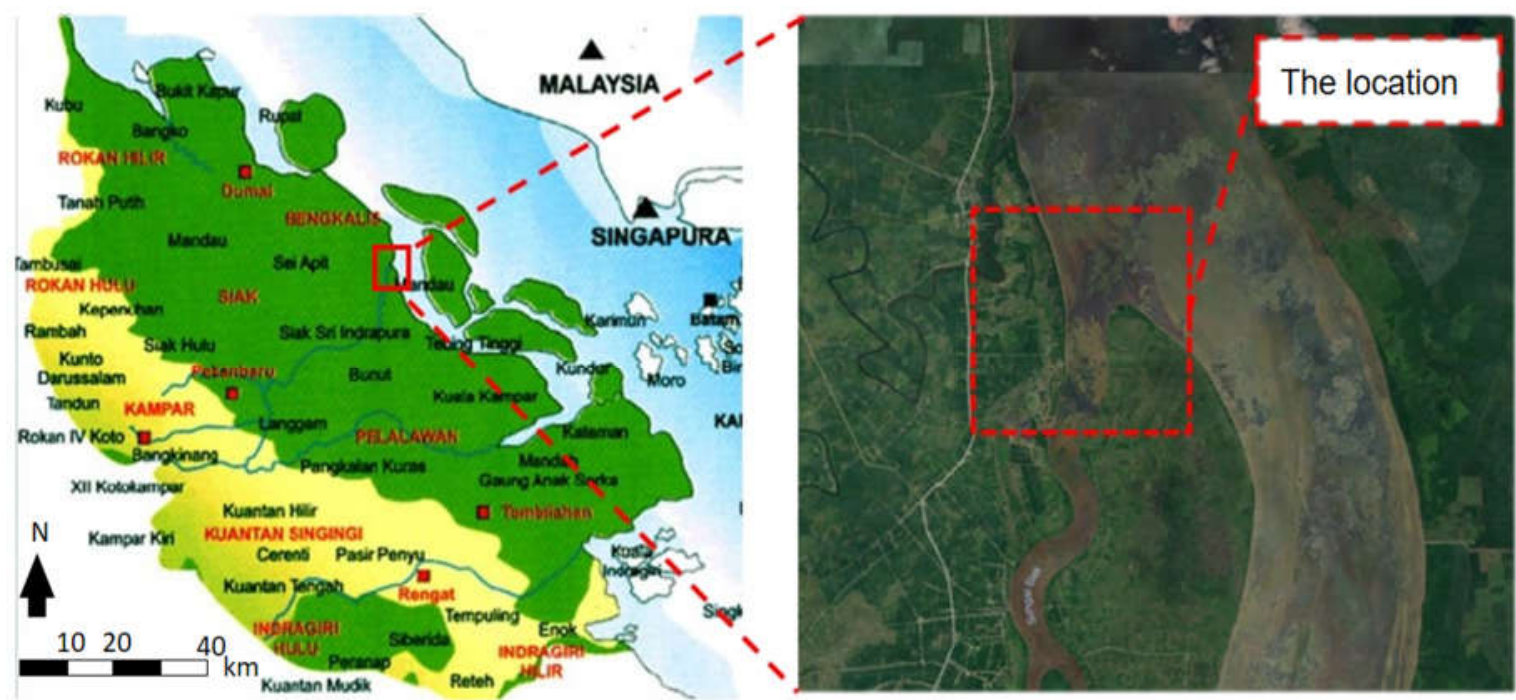

Figure 1. Map of study location.

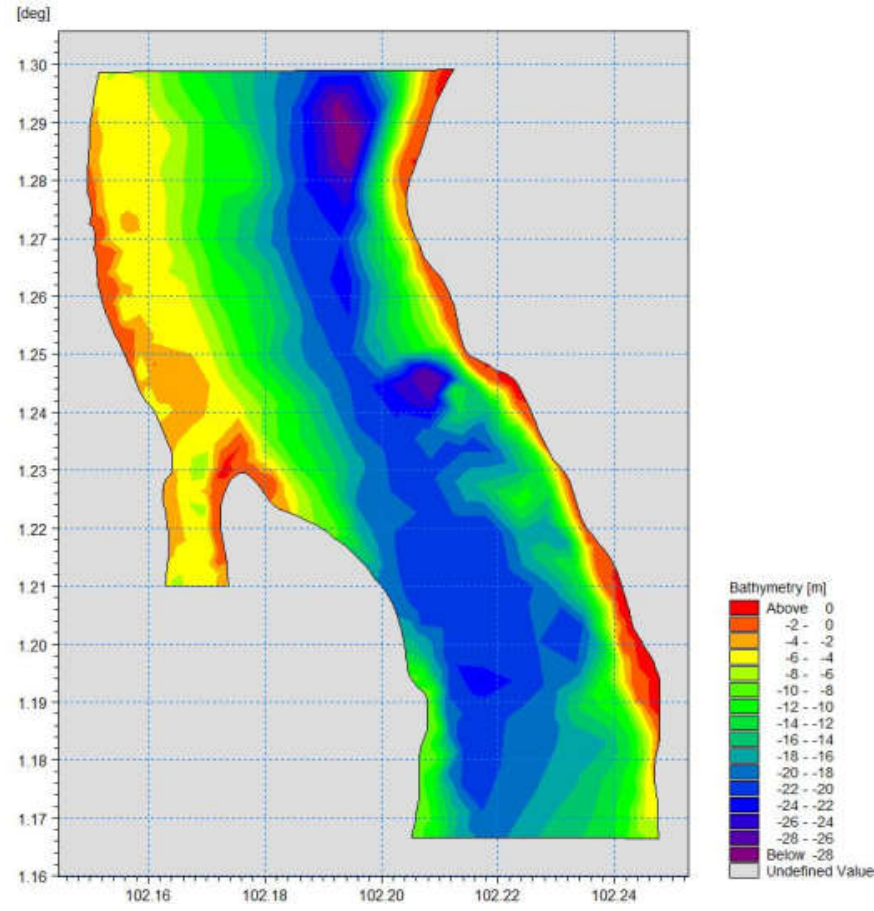

Figure 2. Bathymetry profile of Siak river estuary and Bengkalis strait.

masses are influenced by the Indian Ocean in the north-west part and Java Sea in the south-east part. Generally, the water mass flow in Malacca Strait, including Bengkalis strait, is directed towards the Indian Ocean which is strongly related to the sea level gradient in this strait (Wyrtki 1961).

\section{Boundaries}

In this study, the hydrodynamic simulation is generated by MIKE 21. The model is a horizontal two-dimensional which solved by finite element method. By this numerical model, it can be predicted flow patterns, water level, and horizontal velocity components, both in steady flow and unsteady flow, as well as sedimentation movement.

Determining the boundaries of the area for simulation is crucial. The initial rate of discharge sediment in Siak estuary is set to be $25 \mathrm{mg} / \mathrm{l}$ and settling velocity of $0.015 \mathrm{~mm} / \mathrm{s}$. The
Table 1. Coordinate of the Boundaries

\begin{tabular}{ccc}
\hline Boundary Location & $\begin{array}{c}\text { North } \\
\text { laltitude }\end{array}$ & East longitude \\
\hline Siak River & $1.2111-1.2101$ & $102.1736-102.1629$ \\
Bengkalis Strait & $1.2978-1.2991$ & $102.1513-102.2125$ \\
Bengkalis Strait & $1.1667-1.1690$ & $102.2052-102.2473$ \\
\hline
\end{tabular}

boundaries are taken $1 \mathrm{~km}$ outside of the line study area as a buffer zone for eliminating any inaccuracies (Mubarak et al 2017). In our model, there are three water boundaries, namely in Siak river and Bengkalis strait as depicted in Table 1. The area of simulation is about $87 \mathrm{~km}^{2}$ and the length from mouth Siak estuary is about $1.5 \mathrm{~km}$.

The domain model is the boundary used in modeling and is used as placement of input models and boundary conditions. Domain boundaries are sea and land. Domain boundaries are made larger than the area being reviewed for avoiding the boundary effect that occurs in numerical calculation of current hydrodynamics. The hydrodynamic model is run to simulate currents generated by tides. Current circulation movement in shallow water is assumed to be a homogeneous flow, simulation from the surface to bottom of the water and surface wind influence is assumed to reach the riverbed. So that the model equation used is an equation that is integrated with depth.

Hydrodynamics equation

The main constitutive equation for developing hydrodynamic model is continuity and momentum equation which can be written as follows (DHI, 2011):

Continuity:

$$
\frac{\partial h}{\partial t}+\frac{\partial h \bar{u}_{x}}{\partial x}+\frac{\partial h \bar{u}_{y}}{\partial y}=h s
$$

Momentum:

$$
\begin{aligned}
& \frac{\partial u_{x}}{\partial t}+u_{x} \frac{\partial u_{x}}{\partial x}+u_{y} \frac{\partial u_{x}}{\partial y}+g\left(\frac{\partial h}{\partial x}+\frac{\partial a_{0}}{\partial x}\right)-\frac{\varepsilon_{x x}}{\rho} \frac{\partial^{2} u_{x}}{\partial x^{2}}-\frac{\varepsilon_{x y}}{\rho} \frac{\partial^{2} u_{x}}{\partial y^{2}}+\frac{g u_{x}}{M^{2} h} \sqrt{u_{x}^{2}+u_{y}^{2}}=0 \\
& \frac{\partial u_{y}}{\partial t}+u_{x} \frac{\partial u_{y}}{\partial x}+u_{y} \frac{\partial u_{y}}{\partial y}+g\left(\frac{\partial h}{\partial y}+\frac{\partial a_{0}}{\partial y}\right)-\frac{\varepsilon_{x x}}{\rho} \frac{\partial^{2} u_{y}}{\partial x^{2}}-\frac{\varepsilon_{w y}}{\rho} \frac{\partial^{2} u_{y}}{\partial y^{2}}+\frac{g u_{y}}{M^{2} h} \sqrt{u_{x}^{2}+u_{y}^{2}}=0
\end{aligned}
$$


where $u_{i}(i=x, y)$ is horizontal velocity at $i$-axes, $t$ is time, $g$ is gravitational intensity $\left(9.81 \mathrm{~m} . \mathrm{s}^{-2}\right), h$ is depth of water, $a_{0}$ is elevation from river floor, $r$ is the density, $e_{x x}$ is coefficient of normal turbulent in $\mathrm{x}$-axes, $e_{x y}$ is coefficient of tangential turbulent in $\mathrm{x}$-axes, $e_{y y}$ is coefficient of normal turbulent in $\mathrm{y}$ -axes, $e_{y x}$ is coefficient of tangential turbulent in $y$-axes, and $\mathrm{M}$ is Manning coefficient.

The basis formula of sediment transportation is based on convection-diffusion equation which can be formulated for two-dimensional as follows (Putri and Pohlman, 2014):

$$
\frac{\partial C}{\partial t}+\bar{U}_{x} \frac{\partial C}{\partial x}+\bar{U}_{y} \frac{\partial C}{\partial y}=\frac{\partial}{\partial x}\left(D_{x} \frac{\partial C}{\partial x}\right)+\frac{\partial}{\partial y}\left(D_{y} \frac{\partial C}{\partial y}\right)+\alpha_{1} C+\alpha_{2}
$$

where $\mathrm{C}$ is concentration of sediments, $\bar{U}$ average flow rate in $\mathrm{x}$ and $\mathrm{y}$ axes, $\mathrm{D}$ coefficient of effective diffusion in $\mathrm{x}$ and $\mathrm{y}$ axes, and $a_{1}, a_{2}$ are internal and external coefficient related to the source terms.

\section{Result and Discussion \\ Strait's current profile}

The current that occurs in the Bengkalis Strait waters is the current produced by the long-wave movements caused by tides that propagate from the Malacca Strait. At high tide, the direction of the current propagates from the North to the South and turns east and rejoins with the flow in the Malacca Strait towards the Southeast and part of it goes towards the Bengkalis Strait. Conversely at low tide, the current will move from the east to the west and turn north and out in the Malacca Strait. The level at high tide ranges from $0.49-0.70$ $\mathrm{m}$, while at low tide ranges from $-0.78-0.06 \mathrm{~m}$. The length of the tide is equal to the low tide which is 6 hours. This current pattern which includes direction and speed is an important mechanism in the distribution and transportation of waste pollutants in the Bengkalis Strait waters.

Distribution of TSS is mainly contributed by ocean current, wind and tides (Leonard et al. 1995; Fan et al. 2012). In Bengkalis strait, the ocean energy is swallower from northward by many islands, including Bengkalis island itself. So the ocean current from South China Sea is only slightly affected the strait. But the current from Indian Ocean influences through

Malacca strait channel when southwest monsoon occurred. The current from Java sea also influence, especially in southeast monsoon season (Putri and Pohlmann 2009). The confluence of these two current directions creating a semidiurnal tide phenomenon in most seawater regions of Riau, including in Bengkalis strait as described in Figure 3.

Generally, the Siak estuary emerges a microtidal indication which has a range of fewer than $1 \mathrm{~m}$ of the water surface as shown in Figure 3. Several observers also have reported the presence of mesotidal up to $2.5 \mathrm{~m}$ in Siak estuary when extremely strong flood-tidal currents occur ed (Cecil, 1993). The duration of flood and ebb tide in Siak estuary is not symmetric, the ebb tide occurs for 7-8 hour and flood tide occurs for 4-5 hours (Putri and Pohlmann, 2014). The tide activity in Siak river can reach far away to upstream about $200 \mathrm{~km}$ (Siegel et al. 2009; Putri and Pohlmann, 2014)

Figure 3 also shows that the current tends to move out northward, especially in ebb tide. So that most of the sediment from Siak river is migrated to northward and dispersed in Malacca strait. This phenomenon shows that the northward movement is more dominant, and hence it can be estimated that TSS will spread predominantly northward in the Bengkalis Strait, as a result of the residual circulation (Putri and Pohlmann, 2009). According to Edison et al (2009), the high concentration of sediment transport in the coast is caused by the high suspended particles transported by the waves. This is in line with the results of Mubarak at al (2017) study which explains that the distribution of sediment in the waters is strongly influenced by the wave and the current movements.

\section{TSS distribution}

Figure 4 shows that the concentration of TSS in the form of suspended solid concentration (SSC) fraction at the mouth of the Siak River ranges from 320-400 mg/L. This condition occurs during flood tide where the current from the Bengkalis Strait enters the estuary of Siak River. Meanwhile, higher TSS is founded at ebb tide which is about 400-600 $\mathrm{mg} / \mathrm{L}$ at low tide. The TSS distribution is concentrated near the left side of the Siak estuary because at this point the current from north and south is met, so it creates a plume. It indicated by the orange-red zone in Figure 3 which distance about $6 \mathrm{~km}$ from the mouth of Siak river. The TSS in Siak river is generally low concentration, unless in its estuary region and the strait. The suspended solid in Bengkalis strait is higher than in the Siak estuary because the grain size of sediment is relatively fine and dominated by organic matter (Liebezeit et al. 2014). Moreover, Siak River estuary appears

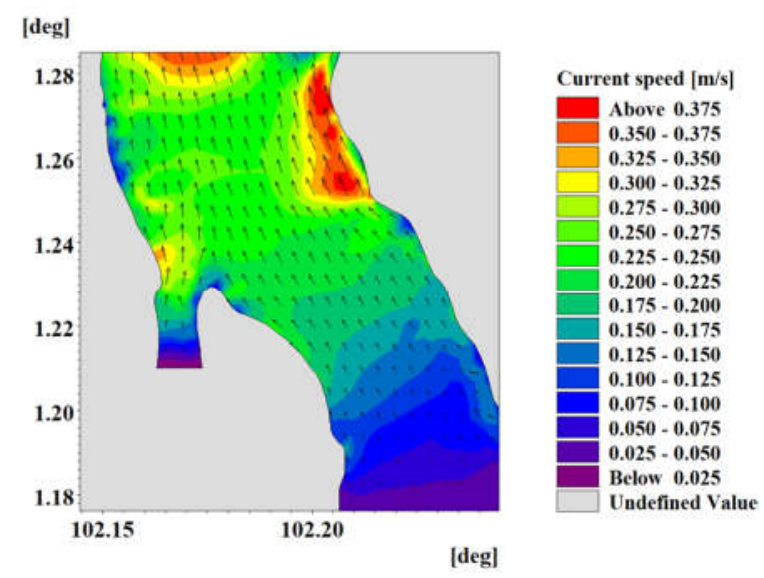

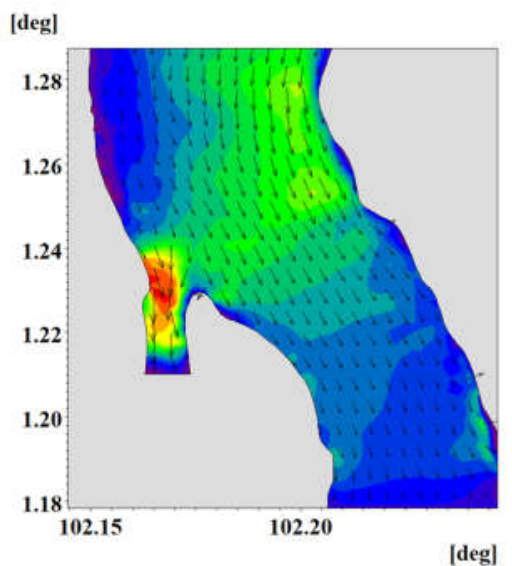

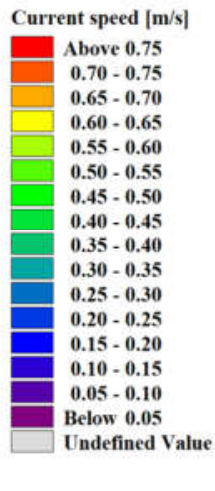

Figure 3. Current direction at flood tide(left) and ebb tide (right). 

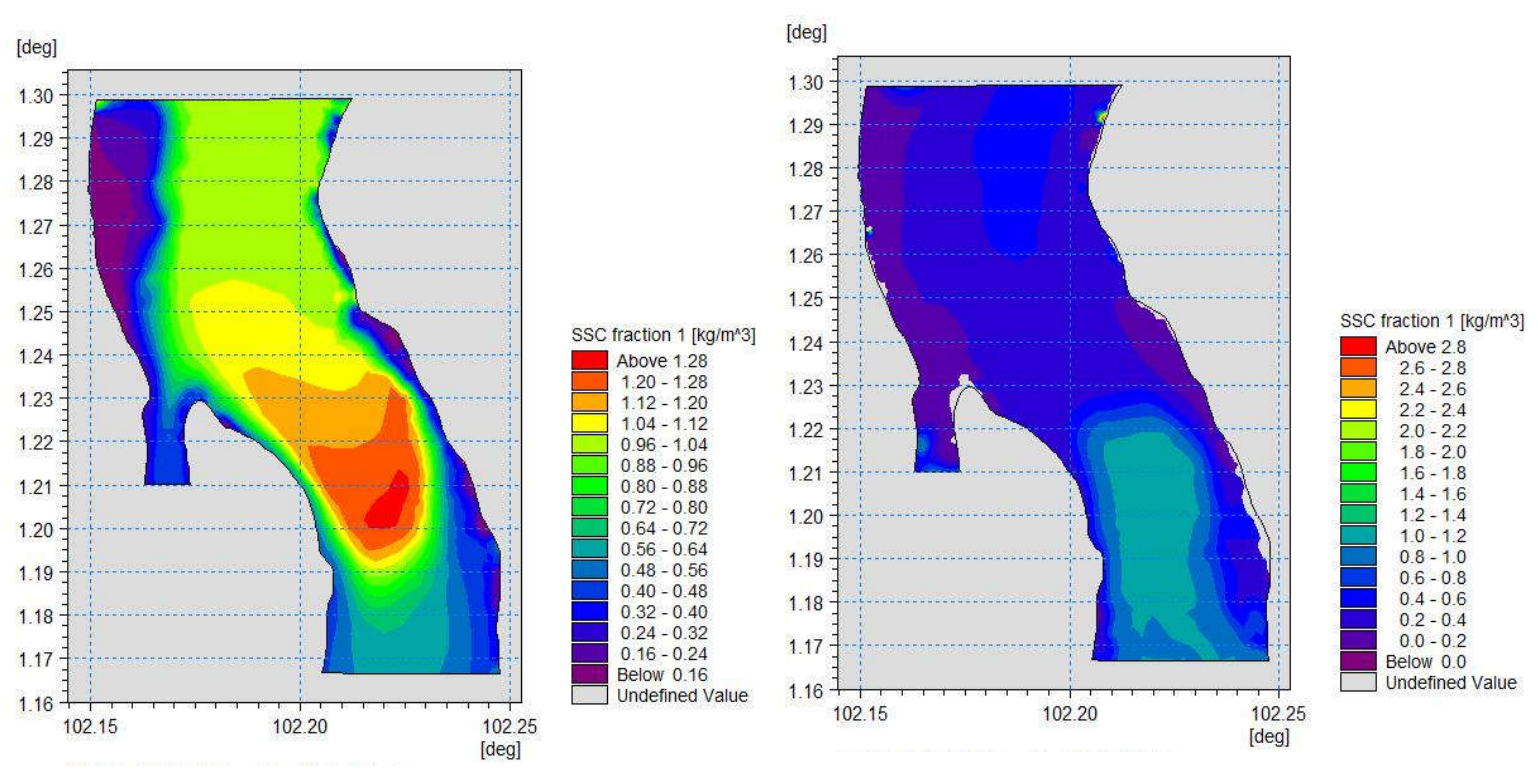

Figure 4. Distribution of TSS concentration at flood (left) and ebb (right) tide.

to be an erosional and/or system, so that the dominant source of mouth-bar sediment to be migrated to the south-part of Bengkalis strait or from tidal-current erosion of the estuary channel (Cecil et al. 1993).

The plume of Siak river which appears in the strait (see figure 4) contains a high density of TSS. Compare to the bathymetry, the TSS in the location is likely dominated by floating substances with very fine grain size. The depth of the plume location is about $14 \mathrm{~m}$ but no significant change. It indicates the bottom sediment is easily eroded and moved to disperse far away to other places, such as in Malacca strait. These results also reported by the previous study which found a high concentration of organic matter in the mouth of Siak river (Liebezeit et al. 2014). Organic sediment can be easily eroded by the wave and tidal currents. The amount of sediment migration in Siak Estuary was dominated by organic matter. Dissolved organic concentration (DOC) in this river is very high. Water discharge in Siak river is varied by month and depends on precipitation rate. The water discharge in Siak river is measured $684 \mathrm{~m} 3 \mathrm{~s}-1$ and export DOC about 39.6 Gton/months to the ocean (Wit et al. 2015). DOC plays a significant role in $\mathrm{pH}$ buffering, by moderating the effects of mineral acid inputs from acid deposition, which increase the acidity of the water (Hruska et al. 1999).

The suspended substances in water consisting of various types, such as fine sand, clay and organic compounds such as cellulose, fat, proteins that float in water or can also be microorganisms such as bacteria, algae, and so on. Additional sources such as petroleum contamination predominantly from boat traffic, domestic waste and industrial discharges, peat erosion and biomass burning do however contribute to the overall organic carbon pool of riverine sediments of the Siak System (Liebezeit et al. 2014). TSS affects sediment deposits in the waters. Moreover, the TSS presence has a negative impact on the quality of water. The visual appearance of the estuary is dark-brown which influencing the turbidity of the water. For Siak river case, DOC is responsible for altering water body appearance to be brown colored (Watts et al. 2001).

This work has proven that water environment in Siak estuary and Bengkalis strait is under risky condition. A huge amount of sediment in the estuary may not affect the vessel traffics in sort time because of high fraction of organic matter in the sediment which prevents particle formation to deposit in the water column (Liebezeit et al. 2014). But, accumulated sediment will be deposited and degraded the depth of Siak River and Bengkalis strait gradually, which may not able to accommodate vessel transportations in the future. Indeed coastal planning attention requires to prevent possible environmental impacts (Putra et al. 2016).

\section{Conclusion}

Sediment movement in Bengkalis strait is mainly supplied by Siak river which driven by water current and tidal activities. Hydrodynamic model shows that TSS dispersion is concentrated in the plume of Siak estuary. Semidiurnal tide is observed is the estuary of Siak river and Bengkalis strait as the confluence of current from Indian Ocean and Java Sea. At flood tide, Siak river discharges TSS in range of 320 to 400 $\mathrm{mg} / \mathrm{L}$. Higher TSS transportation has happened at ebb tide which $400-600 \mathrm{mg} / \mathrm{L}$ floating sediment is exported to Bengkalis strait. The majority of the sediment is in form of organic materials that contain higher DOC. These results indicate that the Siak river mouth has been polluted and is not suitable to be used as raw material for water. So that the restoration efforts may be ignited for preventing any negative impacts and improve the environment.

\section{Acknowledgement}

The author thanks to the Ministry of Research, Technology and Higher Education through LPPM Universitas Riau for their generous and financial support.

\section{References}

Barnard, T. P. (1998). The Timber Trade in Pre-Modern Siak. Indonesia. 65, 86-96.

Baum, A., T. Rixen, and J. Samiaji. (2007). Relevance of peat draining rivers in central Sumatra for the riverine input of dissolved organic carbon into the ocean, Estuarine, Coastal and Shelf Science, 73, 563-570, doi:10.1016/j.ecss.2007.02.012.

Cecil, C. B., F. T. Dulong, J. C. Cobb, and Supardi. (1993). Allogenic and autogenic controls on sedimentation in the central Sumatra 
basin as an analogue for Pennsylvanian coal-bearing strata in the Appalachian basin. Geological Society of America Special Papers, 286, 3-22, doi:10.1130/SPE286-p3.

Davies, S., H. Mirfenderesk, R. Tomlinson, and S. Szylkarski. (2009). Hydrodynamic, Water Quality and Sediment Transport Modeling of Estuarine and Coastal Waters on the Gold Coast Australia, J. Coast. Res., SI 56, 937-941.

DHI (2011) MIKE 21 and MIKE 3 Flow Model FM. Hydrodynamic Module-Short Description. DHI Water \& Environment. Online available at: https://naturstyrelsen.dk/media/nst/65584/54335_ BlueReef_ActionA3_Sed_AppendixA_Short_descriptions.pdf.

Edison, E., Mubarak and L. Bathara. (2009). Characteristics and Sediment Potential in Kampar River Estuary, Journal of Aquatic Science, 7, 11 - 22. doi: https://doi.org/10.23917/forgeo. v31i2. 5290.

Fan, D., G. F. Cai, S. Shang, Y. J. Wu, Y. W. Zhang, and L. Gao. (2012). Sedimentation processes and sedimentary characteristics of tidal bores along the north bank of the Qiantang Estuary, Chin. Sci. Bull. 57, 1578-1539, doi: 10.1007/ s11434-012-4993-6.Hruska, J., S. Kohler, and K. Bishop. (1999). Buffering processes in a boreal dissolved organic carbon rich stream during experimental acidification. Environmental Pollution, 106, 55-65, doi: 10.1016/S0269-7491(99)00061-5.

Leonard, L. A., A. C. Hine, M. E. Luther, R. P. Stumpf, and E. E. Wright. (1995). Sediment Transport Processes in a West-central Florida Open Marine Marsh Tidal Creek: the Role of Tides and Extra-tropical Storms. Estuarine, Coastal and Shelf Science, 41, 225-248, doi: 10.1006/ecss.1995.0063.

Liebezeit, G., R. Wöstmann, and D. Ziehe. (2014). Biomarkers in the Siak River System, E. Sumatra, Indonesia. Asian Journal of Water, Environment and Pollution, 11: 25-40.

Menendez, A. N., N. D. Badano, M. F. Lopolito, and M. Re. (2013). Water quality assessment for a coastal zone through numerical modeling, Journal of Applied Water Engineering and Research, 1, 8-16, doi: 10.1080/23249676.2013.827892

Mubarak, A. Sulaiman and Efriyeldi. (2017). Environmental Effect of Tidal Bore Propagation in Kampar River. MATEC Web of Conferences 103, 04015, doi: 10.1051/matecconf/201710304015.

Mubarak, S. Sutikno, R. D. Merian. (2017). Numerical model for pollutant dispersion in the Dumai estuary, MATEC Web of Conferences 101, 04001, doi: 10.1051/matecconf/201710104001

Putra, J.R., Rifardi, and Mubarak. (2016). Analisis Sedimentasi di Muara Sungai Rokan Provinsi Riau. Berkala Perikanan Terubuk, 44, 90 - 103.

Watts, C.D., P. S. Naden, J. Machell, and J. Banks. (2001). Long term variation in water colour from Yorkshire catchments, Science of the Total Environment, 278, 57-72, doi: 10.1016/ S0048-9697(00)00888-3.

Wit, F., D. Müller, A. Baum, T. Warneke, W. S. Pranowo, M. Müller, and T. Rixen. (2015). The impact of disturbed peatlands on river outgassing in Southeast Asia. Nature Communications, 6, 10155(1-9), doi: 10.1038/ncomms10155.

Wyrtki, K., (1961). Physical Oceanography of the Southeast Asian waters, Scientific Results of Marine Investigations of the South China Sea and the Gulf of Thailand 1959-1961, NAGA Report, 2, 17-28.

Yupi, H. M., T. Inoue, J. Bathgate and R. Putra. (2016).Concentrations, loads and yields of organic carbon from two tropical peat swamp forest streams in Riau Province, Sumatra, Indonesia. Mires and Peat, 18, Article no. 14, doi: 10.19189/MaP.2015.OMB.181 